高分子化学 (Kobunshi Kagaku), Vol. 30, No. 343, pp. 667-672 (Nov., 1973)

\title{
PVC のメッキ性に対するトリチオシアヌル酸塩の作用
}

\author{
（受付1973年 3 月 20 日・掲載決定 1973 年 8 月 3 日）
}

中村儀郎*1 ・森 邦夫*1 ・杉本一美*1

\begin{abstract}
要 旨 トリチオシアヌル酸・1ナトリウム塩 $(\mathrm{TTCA} \cdot \mathrm{Na})$ を混練したポリ塩化ビニル $(\mathrm{PVC})$ 板は，水洗浄を行ならたけで直ちに，塩化第一スズのような感応化試剤と板表面でメルカプチドを 形成して感応化を受け，つぎのメッキ工程に供することができる。さらに，この場合得られるメッ キ層のはく離強度は, PhG の上うな親水性高沸点浴媒を混練することによって一層增加する。

また, チオフェノール， $\beta$ チオナフトール，チオグリコール酸オクチルェステル，または，2-ジ プチルアミノ-4, 6-ジチオー-トリアジンのようなチオールのメルカプチドに比較して, 上り強い還 元力を有する TTCA のスズ(II), 銀, 銅メルカプチドを混練した PVC 板は, 水洗または, DMF 処理を行なうだけで，感応化工程，あるいは，活性化工程を省略して，直接化学銅メッキ工程に進 むことができる。

ここに得られるメッキ層のはく觹強度は，0.1 1.5 kg/cm である。
\end{abstract}

\section{1. 緒言}

プラスチックに対するメッキ工程の多くは，その表面 に塩化第一スズのような還元性試剤の吸着(感応化工程) に続いて，その表面にパラジウム，銀のような易還元性 金属を析出させて電導性を与える操作（活性化工程）を メッキの前処理工程として実施するのが一般的である。

著者らが，先に報告したジメチルホルムアミド (DMF) 漫せきによるポリ塩化ビニル (PVC) のメッキ法”ににお いても, その感応化工程として PVG 板表面に還元力を 有する DMF・塩化第一スズ錯体 ${ }^{2)}$ の形成を行なって $\mathrm{P}$ $\mathrm{VC}$ メキの成功をみた。このような目的に用いられる 還元性物質としては，ナイロン，ポリ（モノクロロトリ フルオロエチレン)に対するトリス（ヒドロキシメチル） ホスフィン3), ABS, ポリプロピレン, ポリカーボネート に対する塩化第一アンチモン，塩化第一七素と硫化水素 の組合せ4)，または，カルボキシル基在有するカチオン 活性剂のスズ㙁 ${ }^{5}$ などがすでに知られているが，本報で 述べるトリチオシアヌル酸 (TTCA) 塩類のプラスチッ クメッキへの応用については全く知られていない。思う に, TTCA・1 ナトリウム塩 (TTCA・Na) はPVC とよ く混練できる特徵と感応化, および活性化工程で用いら れるスズ，銀イオンと酸性下でも塩（メルカプチド）を 形成する性質()を有するから，この化合物の PVC のメ ッキに対する適応性を検討することは，PVCメッキを より一般化するために必要なことと考える。 本報に扢いては，これら化合物のPVCへの混練特性 *1 岩手大学工学部応用化学科 (广 020-01 盛岡市上田 4)

激分子化学, Vol. 30, No. 343 (Nov., 1973)
と板表面の親水性向上に効果のある可塑剤の選択およ び, TTCA 塩類の PVCメッキに対する特性について述 べる。

\section{2. 実験}

\section{1 試薬およひ原料}

PVC は，日本ゼオン侏製 $101 \mathrm{EP}(\bar{P}=1450)$, グリコ 一ル類は, 日本乳化㓮(侏), 可塑剤は大八化学工業(侏), $\mathrm{T}$ TCA およびその誘導体は三協化成侏からそれぞれ供与 されたものを用いた。

その他の試薬は市販一級品をそのまま用いた。

\section{2 メルカプチドの製造}

$5 \sim 10 \mathrm{~g}$ のチオール類を $50 \mathrm{~m} l$ の水またはメタノール に溶解後， 3 \% 硝酸銀水溶液， 4 \% 硫酸銅水溶液, また は 4 \%塩化第一スズ溶液 (0.8\%塩酸性)にそれぞれ加え, $20^{\circ} \mathrm{C} て ゙ 6$ 時間かきまぜた。生成したメルカプチドはロ過 後口液に金属イオンの定性をみなくなるまで純水で洗浄 し, 真空乾燥器で $80^{\circ} \mathrm{C}, 48$ 時間乾燥した。それぞれの組 成を Table 1 に示す。

\subsection{PVG 板の製造}

Table 3, 5, 6 に示才配合剤を熱ロールで, $120^{\circ} \mathrm{C}, 5$ 分 混練し，シートをつくる。これをステンレス製金型で $130^{\circ} \mathrm{C}, 5$ 分加熱後, $50 \mathrm{~kg} / \mathrm{cm}^{2}$ に加压しつつ 5 分間に約 $30^{\circ} \mathrm{C}$ まで泠却して $2 \times 40 \times 50 \mathrm{~mm}$ の試料板をつくった。 ただし，混練板の機械的性質の測定用試料はロールおよ びプレス温度をそれぞれ $160^{\circ} \mathrm{C} ， 170^{\circ} \mathrm{C}$ とた。

\section{$2.4 メ ッ キ 工$ 程}

\subsection{1 洗浄工程}

脱脂液 (カセインーダ $20 \mathrm{~g} / l$, 高級アルコール型アニオ 
ン系洗剤 $50 \mathrm{~g} / l)$ て $20^{\circ} \mathrm{C}, 5$ 分脱脂した PVC 板を $30^{\circ} \mathrm{C}$ の 水で 4 時間かきまぜ洗浄し，つぎの工程に用いた。メタ ノール，エーテルによる洗浄は，PVC 板を $20^{\circ} \mathrm{C}$ の溶媒 に Table 4 の条件で浸せき洗浄した。これらの洗浄は, 30分ごとに新しく溶媒を取りかえて行なった。

\section{4 .2 感応化工程}

洗浄板を直ちに $2 \%$ 塩化第一スズ溶液 (0.8\%塩酸性) に, $20^{\circ} \mathrm{C}, 1$ 時闍浸せきしたのち, 流水で 5 分洗浄後純 水で洗浄した。

\subsection{3 活性化工程}

感応化を終わった板を，直ちに $2 \%$ 硝酸銀水溶荋に 20 ${ }^{\circ} \mathrm{C} ， 30$ 分浸せきし，板表面に銀を析出させた。これを流 水で 5 分洗浄後純水で洗浄した。

\section{4 .4 化学銅メッキ工程}

銀または，銅メルカプチドを混練した板は $4 \sim 6$ 時間 水洗後, あるいは，活性化を終えた板は直ちに化学眮义 ッキ液（A液：硫酸銅 5 水塩 $35 \mathrm{~g} / l$, カセイソーダ $49 \mathrm{~g}$ $/ l$, 酒石酸カリウムナトリウム $170 \mathrm{~g} / l ; \mathrm{B}$ 液：37\%ホル マリン；A液 5 容にB液 1 容を混合した溶液)に, $20^{\circ} \mathrm{C}$, 60 分浸せき後ブラッシングして流水で 5 分洗浄後純水で 洗浄した。

\subsection{5 電気銅メッキ工程}

化学銅メッキを終えた板に対して前報1) と同様の条件 で電気メッキを行ないメッキ燐 $0.05 \mathrm{~mm}$ の試料をつく った。

\section{5 試験および測定法}

板表面の臨界表面張力 $\left(r_{c}\right)$ およびメッキ層のはく離
強度の測定，および熱サイクル試験はすべて前報1)の方 法によった。

酸化還元電位は色素法”によった。すなわち電位既知 の色素の $10^{-4}$ モル溶液に試料粉末 $0.1 \mathrm{~g}$ を加え, $\mathrm{pH}=$ 7 にで， $20^{\circ} \mathrm{C} ， 1$ 時間放置後その色調を観察した。用い た色素と $\mathrm{pH}=7$ に抢ける酸化還元電位は,フェノール ブルー $(224 \mathrm{mV})$, トルイレンブルー $(115 \mathrm{mV})$, メレ ンブルー $(15 \mathrm{mV})$, サフラニン $\mathrm{T}(-289 \mathrm{mV})$, フェノ ールレッド $(-385 \mathrm{mV})$ である。

\section{6 分 析}

銀メルカプチド，および析出銀の銀定量は，試料約0.1 $\mathrm{g}$ を精ひょうし, これを檂硝酸で加熱分解後, 水で約 1 規定に希釈し，ホルハルト法により行なった。

銅メルカプチド，および析出銅の銅定量は，試料約 0.1 $\mathrm{g}$ を精ひょうし，これを濃硝酸で加熱分解後，浱硫酸を 加え硝酸を除却し，さらに尿素を加え亜硝酸を完全に除 却したのち, 水で約10倍に希䣋しヨウ素滴定法により行 なった。

\section{3. 結果と考察}

\subsection{TTCA 塩類の還元郕としての性質}

TTCA の金属塩（メルカプチド）の生成条件について はすでに報告しだ)が，メッキ工程で形成されるメルカ プチドおよび他のチオール類のメルカプチドの組成とこ れらの酸化還元電位を Table 1 に示す。

メッキ工程で形成される TTCA のメルカプチドの還 元力をそれぞれの酸化還元電位から比較すると，ナトリ

Table 1. Analysis and redox potential of mercaptides.

\begin{tabular}{|c|c|c|c|c|c|}
\hline \multirow{3}{*}{ Compounda) } & \multicolumn{4}{|c|}{ Mercaptide } & \multirow{3}{*}{$\begin{array}{l}\text { Redox potential } \\
\quad E_{0}(\mathrm{mV})\end{array}$} \\
\hline & \multicolumn{2}{|c|}{ Metal $(\%)$} & \multicolumn{2}{|c|}{$\mathrm{N}(\%)$} & \\
\hline & Found & Calcd. & Found & Calcd. & \\
\hline $\mathrm{TTCA} \cdot \mathrm{Na} 3 \mathrm{H}_{2} \mathrm{O}$ & - & - & - & - & $>224$ \\
\hline T'TСA.Ag & 38.60 & 37.96 & 14.64 & 14.75 & $-289 \sim-385$ \\
\hline TTCA.2Ag & 55.36 & 55.24 & 10.71 & 10.72 & $-289 \sim-385$ \\
\hline ГTCA.3Ag & 62.14 & 65.19 & 8. 34 & 8.44 & $-289 \sim-385$ \\
\hline TTCA.Sn (II) & 37.14 & 40.32 & 15.72 & 14.34 & $11 \sim-289$ \\
\hline TTCA $\cdot 0.5 \mathrm{Cu}$ & 16.07 & 15. 23 & 19.64 & 20.16 & $11 \sim-289$ \\
\hline TTCA.Cu & 27.88 & 26.59 & 17.13 & 17.57 & $11 \sim-289$ \\
\hline TTCA $1.5 \mathrm{Cu}$ & 33.01 & 35.33 & 15.97 & 15.55 & $11 \sim-289$ \\
\hline $\mathrm{DBTT} \cdot 2 \mathrm{Ag}$ & 44.78 & 45.72 & 9.03 & 8. 89 & $>224$ \\
\hline $\mathrm{DBTT} \cdot \mathrm{Sn}(\mathrm{II})$ & 28.98 & 31.64 & 11.97 & 11.20 & $224 \sim 11$ \\
\hline Thiophenol·Ag & 46.09 & 49.68 & 20.79 & 19. 32 & $>224$ \\
\hline$\beta$-Thionaphthol $\cdot \mathrm{Ag}$ & 40.53 & 40.60 & 15. 88 & 15. 79 & $224 \sim 11$ \\
\hline $\mathrm{OTG} \cdot \mathrm{Ag}$ & 35.72 & 34.62 & 13.01 & 13. 46 & $224 \sim 11$ \\
\hline
\end{tabular}

a) TTCA: Trithiocyanuric acid, DBTT: 2-dibutylamino-4,6-dithio-s-triazine, OTG: Octyl thioglycolate 
PVC のメッキ性に对するトリチオシアヌル酸篮の作用

ウム塩くスズ (II)塩，銅（II）塩＜銀塩の順に還元力が大 となる。

さらにこれら TTCA のメルカプチドは，チオフェ， ール， $\beta$-チオナフトール，およびチオグリコール酸オク チルエステルのようなモノチオールの銀塩，あるいは， 2-ジブチルアミノ-4, 6-ジチオ-s-トリアジンの銀塩に比 較してはるかに強い還元力を有する。

このため TTCA 銀塩は，活性化および化学銅メッキ 工程に用いる硝酸銀扔よび硫酸銅・アルカリ溶液との接 触により Table 2 に示すようにそれぞれの金属を析出す る特性を最も顕著に示し，プラスチックメッキの助郕と しての効果が期待される。

このような TTCA.Sn (II) または, TTCA.3Ag で代 表的に示される金属イオンに対する還元的析出能力は, 単なるイオン交換ではなく*1)， $\mathrm{Sn}^{2+}$ のような低原子佃 塩類の邀元力，またはすでにシステインの鈈塩について 認められている銅または銀イオンに対する吸着力8) と同 様の理由によるもの上考えられるが，詳細は不明であ る。
Table 2. Deposition of metal by mercaptide.

\begin{tabular}{|c|c|c|c|}
\hline \multirow{2}{*}{ Mercaptide ${ }^{a}$} & \multirow{2}{*}{$\begin{array}{c}\text { Reac- } \\
\left.\text { tion }{ }^{b}\right) \\
\text { condition }\end{array}$} & \multicolumn{2}{|c|}{$\begin{array}{l}\text { Deposited metal } \\
\text { (mg/g mercaptide) }\end{array}$} \\
\hline & & $\mathrm{Ag}^{\mathrm{c})}$ & $\mathrm{Cu}^{\mathrm{d})}$ \\
\hline TTCA.3Ag & A & $124.8(30.3)$ & 635 \\
\hline TTCA.Sn (II) & $\mathrm{B}$ & $147.0(35.0)$ & 531 \\
\hline $\mathrm{TTCA} \cdot 1.5 \mathrm{Cu}$ & A & & 188 \\
\hline DBTT $\cdot 2 \mathrm{Ag}$ & A & $62.0(11.8)$ & \\
\hline $\mathrm{DBTT} \cdot \mathrm{Sn}(\mathrm{II})$ & $\mathrm{B}$ & $54.0(27.0)$ & \\
\hline Thiphenol·Ag & A & $38.4(2.9)$ & \\
\hline$\beta$-Thionaphthol $\cdot \mathrm{Ag}$ & A & $41.4(5.8)$ & \\
\hline OTG $\cdot A g$ & A & $76.1(7.2)$ & \\
\hline
\end{tabular}

a) TTCA, DBT $\mathrm{r}$, and OTG refer to Table 1, b) A: Reaction temp., and time are $20 \mathrm{C}$, and $24 \mathrm{hr}$, respectively, B: Reaction temp., and time are $20^{\circ} \mathrm{C}$, and $3 \mathrm{hr}$, respectively, c) Deposited from $2^{\circ} \%$ diamminesilver solution, ( ) : deposited from $2^{\circ}$; silver nitrate solution, d) Deposited from $5{ }^{n}$, cuprammonium solution

Table 3. Mechanical, and metal-plating properties of PVC blended with glycols and TTCA $\cdot \mathrm{Na}$.

\begin{tabular}{|c|c|c|c|c|c|c|c|}
\hline Plasticizer ${ }^{b}$ ) & (phr) & $\begin{array}{c}\text { TTCA } \cdot \mathrm{Na}^{\mathrm{a})} \\
(\mathrm{phr})\end{array}$ & $\begin{array}{c}\left.\mathrm{T}_{\mathrm{B}} \mathrm{c}\right) \\
\left(\mathrm{kg} / \mathrm{cm}^{2}\right)\end{array}$ & $\begin{array}{l}\left.E_{B}{ }^{d}\right) \\
(\%)\end{array}$ & $\begin{array}{c}\gamma_{c} \\
(\mathrm{dyn} / \mathrm{cm})\end{array}$ & $\begin{array}{c}\mathrm{SnCl}_{2} \\
\text { adsorbed } \\
\left(\mathrm{Sn} \mathrm{mg} / \mathrm{cm}^{2}\right)\end{array}$ & $\begin{array}{c}\text { Peel } \\
\text { adhesion } \\
(\mathrm{kg} / \mathrm{cm})\end{array}$ \\
\hline \multirow[t]{2}{*}{ DBP } & 10 & 0 & 467.6 & 115.5 & 24.2 & 0.010 & - \\
\hline & 30 & 0 & 204.4 & 188.0 & 23.7 & & 一 \\
\hline \multirow[t]{2}{*}{$\mathrm{PhG}$} & 10 & 0 & 455.3 & 173.2 & 29.1 & 0.057 & 一 \\
\hline & 30 & 0 & 332.2 & 243.3 & 33.8 & & 一 \\
\hline \multirow[t]{2}{*}{ BTG } & 10 & 0 & 412.1 & 210.0 & 32.1 & 0.021 & 一 \\
\hline & 30 & 0 & 221.7 & 272.0 & 34.9 & & 一 \\
\hline \multirow[t]{3}{*}{ DIBP } & 10 & 5 & 404.0 & 33.5 & 24.2 & 0.048 & $0 \sim 0.1$ \\
\hline & 10 & 10 & 402.1 & 21.5 & 24.6 & & 0.2 \\
\hline & 10 & 20 & 416.0 & 20.5 & 25.8 & 0.029 & 0.2 \\
\hline \multirow[t]{3}{*}{$\mathrm{PhG}$} & 10 & 5 & 398.2 & 153.3 & 32.8 & 0.072 & 0.5 \\
\hline & 10 & 10 & 422.5 & 105.0 & 31.9 & & $1.0 \sim 1.8$ \\
\hline & 10 & 20 & 386.5 & 75.2 & 30.9 & 0.081 & 1.5 \\
\hline \multirow[t]{3}{*}{ BTG } & 10 & 5 & 395.8 & 150.1 & 33.2 & 0.018 & 0.6 \\
\hline & 10 & 10 & 435.4 & 105.0 & 32.1 & & 1.1 \\
\hline & 10 & 20 & 364.9 & 83.2 & 33.4 & 0.068 & $1.0 \sim 1.3$ \\
\hline $\mathrm{PhG}$ & 30 & 10 & 351.1 & 110.7 & 35.1 & & 1.6 \\
\hline BTG & 30 & 10 & 278.5 & 121.7 & 35.5 & & 1.0 \\
\hline DBP & 30 & 10 & 199.2 & 161.5 & 23.9 & & 0.2 \\
\hline \multirow[t]{2}{*}{ non. } & 0 & 10 & 333.0 & 86.3 & 33.0 & & 0.3 \\
\hline & 0 & 20 & 365.0 & - & 33.1 & 0.069 & 0.6 \\
\hline
\end{tabular}

a) Trithiocyanuric acid monosodium salt, b) DBP: Dibutylphthalate, PhG: Ethyleneglycol monophenylether, BTG: Triethyleneglycol monobutylether, c) $T_{B}$ : Tensile strength, d) $E_{B}$ : Elongation at break

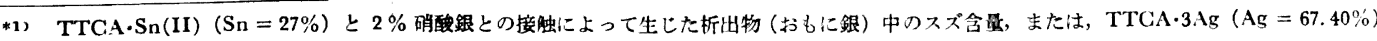
と 5 \% 硫酸銅・アルカリ溶液との接触により生した析出物（おるに铜）中の銀含量は，いずれも変化ない。 


\subsection{TTGA·Na およひ親水性可塑剂と PVG との混 和性}

$\mathrm{TTCA} \cdot \mathrm{Na}$ は, $\mathrm{mp} 300^{\circ} \mathrm{C}$ 以上, 不揮発性, 無臭の卜 リチオール化合物の三水塩で，空気中 $170^{\circ} \mathrm{C} ， 30$ 分加熱 しても全く酸化されない安定な化合物であり，さらにそ の水溶液から種々の不溶性メルカプチドを形成すること ができる6)。

いま, TTCA・Na と PVC との混練性を混練成型板の 機械的性質から検討すると， Table 3 に示すように， T TCA.Na が $20 \mathrm{phr}$ 以上となると破断伸度がいちじるし く低下するが，10 phr 以下の混練量では成型板の物性を とくに低下させることがなく，その混練性は比較的良好 といえる。

一方，親水性はないが， PVCメッキに良好な結果を 示した可塑刋1)であるジブチルフタレート (DBP, 溶解度 パラメーター $(\mathrm{SP})=9.42)$ に代わって，板表面の親水 性を向上させる効果のある，エチレングリコールモノフ エニルエーテル $\left(\mathrm{PhG}, \mathrm{SP}=9.88, \mathrm{bp}=244.7^{\circ} \mathrm{C}\right)$, トリ エチレングリコールモノブチルエーテル (BTG, SP = $\left.8.52, \mathrm{bp}=271.2^{\circ} \mathrm{C}\right)$ のような親水性高沸点溶媒と PVC ( $\mathrm{SP}=9.4$-9.7) との混練性を 混練成型板の機械的性質 から検詩した。

Table 3 に示すように, PhG, BTG ともに, 10 30 $\mathrm{phr}$ 程度の添加量で，常温においては DBP と近似の物 性を与えることから，このような親水性高沸点溶媒を $\mathrm{P}$ $V C$ に混練して，親水性成型板を製作できる可能性があ る。さらに，これらグリコールエーテルを多量 (30 phr) に混練した軟質 PVC に対し，TTCA・Na を添加すると DBPには見られないような板の強鞄性の改良にも役立 つ。上結果から，TTCA.Na と $\mathrm{PhG，または} \mathrm{BTG}$
をPVGに混練して以下述べるメッキ用 PVC 板を作製 することは，実用的に意味があるものと考える。

\section{3 混練板表面の性澌}

感応化工程で用いる塩化第一スズ溶液から容易にメル カプチドを形成できる TTCA.Naを混練した PVC 板 は, 感応化工程で TTCA·Na を含まない板より，スズ （II）イオンをやや多く吸着し，この傾向は，TTCA·Na の添加量の増加また PhG のような親水性高沸点溶媒を 泿練した場合にとくに顕著となる (Table 3)。

一方, $\gamma_{0}$ からは, 両者の表面状態の親水性の差異は 判断しがたいが，これらの配合剤の影整は，一般にメッ キ層のはく離強度の増加に効果を示すことが Table 3 か ら認められる。

また，板表面の水洗効果は，Table 4 に示すように, 親水性のない DBP のような可塑剤を混練した場合より 親水性に富むP PhG, BTG を混練した場合にとくにはく 離強度の增加に寄与する。さらに, 洗浄剤の種類または 洗浄時間の変化が板表面の $\gamma_{c}$, はく離強度に大きな影警 を及ぼすことが同表からわかる。すなわち，メタノール は水に比較して， TTCA・Na，グリコールをより一層強 く溶解するため，PVG 板表面からこれら試剤が溶出し， 表面の粗面化による親水性の増加にもかかわらず，はく 離強度は増加しない。

一方，エーテルは，混練板表面からグリコールだけを 溶出するから, 表面の粗面化とともに, 残存 TTCA·Na による $\gamma_{c}$ の堌大が認められるが，感応化試剤，活性化 試凪の浸透が不十分となり，十分なはく離強度を示さな い。

結果的に, Table 3, 4 に示すように, PhG 10 30 phr に TTCA・Na 10〜20 phr を混練した PVC 板を $30^{\circ} \mathrm{C}, 4$

Table 4. Effect of washing process on critical surface tention $\left(\gamma_{c}\right)$ and peel adhesion.

\begin{tabular}{|c|c|c|c|c|c|c|c|c|c|c|c|c|}
\hline \multirow{3}{*}{ Sample } & & \multicolumn{11}{|c|}{ Washing process (min) } \\
\hline & & \multicolumn{3}{|c|}{ Waterb) } & \multicolumn{3}{|c|}{ Methanole) } & \multicolumn{3}{|c|}{ Ether ${ }^{d)}$} & \multicolumn{2}{|c|}{$\begin{array}{c}\text { Cyclo- } \\
\text { hexanone }\end{array}$} \\
\hline & & 30 & 120 & 360 & 30 & 120 & 360 & 30 & 120 & 360 & 10 & 20 \\
\hline \multirow{2}{*}{ I } & $\gamma_{0}(\operatorname{dyn} / \mathrm{cm})$ & 24.5 & 24.8 & 24.6 & 31.3 & 31.8 & 33.6 & 31.1 & 32. 1 & 35.8 & - & - \\
\hline & $\begin{array}{l}\text { Peel adhesion } \\
(\mathrm{kg} / \mathrm{cm})\end{array}$ & 0.2 & 0.2 & 0.2 & 0.2 & 0.3 & 0.3 & 0.4 & 0.6 & 0.7 & 一 & - \\
\hline \multirow{2}{*}{ II } & $\gamma_{c}(\mathrm{dyn} / \mathrm{cm})$ & 32.1 & 32.0 & 32.1 & 32.1 & 31.8 & 32.1 & 34.3 & 33.8 & 35.3 & 33.8 & 37.8 \\
\hline & $\begin{array}{c}\text { Peel adhesion } \\
(\mathrm{kg} / \mathrm{cm})\end{array}$ & 0.7 & 0.8 & 1.1 & 0.3 & 0.5 & 0.4 & 0.3 & 0.6 & 0.7 & 0.6 & 2.0 \\
\hline \multirow{2}{*}{ 面 } & $\gamma_{c}(\mathrm{dyn} / \mathrm{cm})$ & 31.8 & 32.1 & 32.0 & 32.9 & 32.2 & 32.4 & 32.9 & 33.1 & 36.4 & 34.1 & 39.6 \\
\hline & $\begin{array}{l}\text { Peel adhesion } \\
(\mathrm{kg} / \mathrm{cm})\end{array}$ & 0.7 & 0.7 & 1.0 & 0.2 & 0.4 & 0.4 & 0.3 & 0.5 & 0.6 & 0.3 & 0.4 \\
\hline
\end{tabular}

a) I: Blends with $10 \mathrm{phr}$ of DBP and $10 \mathrm{phr}$ of TTCA.Na, II: Blends with $10 \mathrm{phr}$ of PhG and $10 \mathrm{phr}$ of TTC $\mathrm{A} \cdot \mathrm{Na}$, III : Blends with $10 \mathrm{phr}$ of BTG and $10 \mathrm{phr}$ of TTCA.Na, b) Washing in water at $30^{\circ} \mathrm{C}, \mathrm{c}$ ), d) Immersing in the solvent at $20^{\circ} \mathrm{C}$, and solvent was exchanged at $30 \mathrm{~min}$. intervals, e) Immersing in $7^{\circ}, \mathrm{o}$ cyclohexanone solution at $50^{\circ} \mathrm{C}$. 

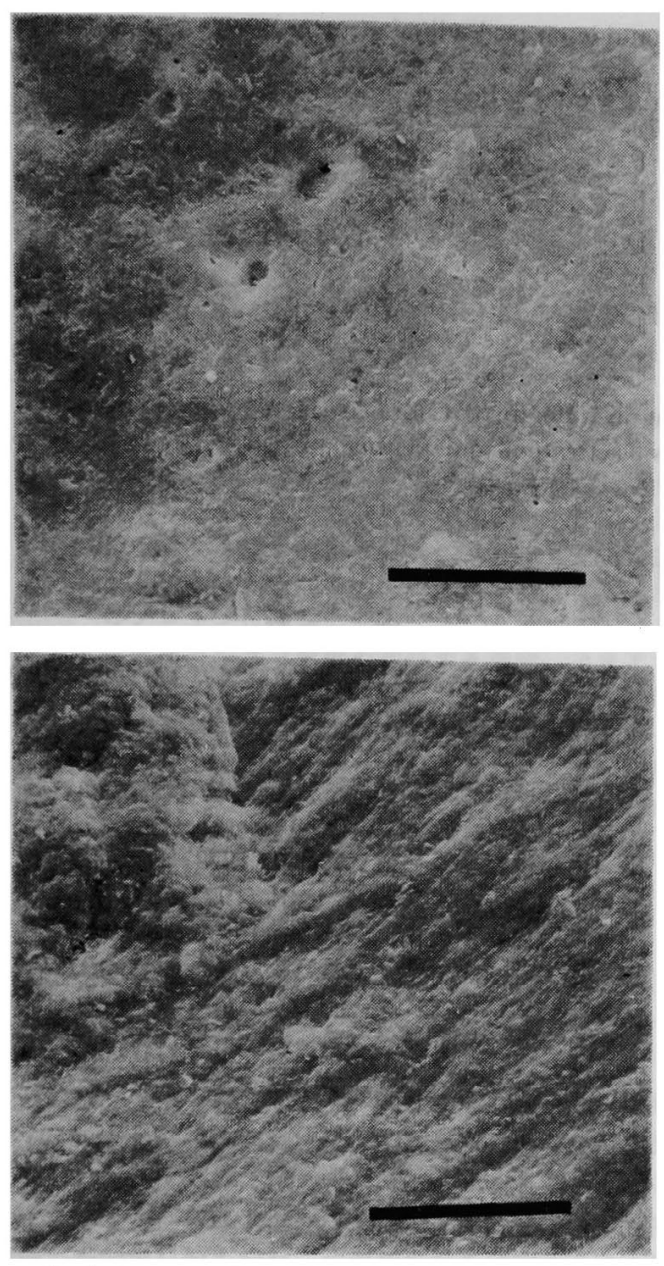

A: Before washing with water, B: After washing with water at $30^{\circ} \mathrm{C}$ for $6 \mathrm{hr}$ $\mathrm{A}$ and $\mathrm{B}$ : blends with $10 \mathrm{phr} \mathrm{PhG}$ and $10 \mathrm{phr}$ TTCA.Na. A and B scale bar $=30 \mu$

Fig. 1. Micrographs of PVC surface.

時間水洗浄を行なったものが，1.0〜 $1.5 \mathrm{~kg} / \mathrm{cm}$ のはく離 強度を示す。

この場合の水洗効果は，洗浄によるグリコールエーテ ルの溶出による板表面の粗面化 (Fig. 1) とともに, PhG の水との親和性 $(\mathrm{PhG} 2.7 \mathrm{~g}$ 水 $100 \mathrm{~g}$, 水 $10.8 \mathrm{~g} / \mathrm{PhG} 100$ g)のため，板表面に微量の水を含んだ PhG の上うな弱 以膨潤郕の親水性吸着層が形成され，感応化試剤（塩化 第一スズ）の PVC 表面層への浸透を容易にし, 結果的 に, 塩化第一スズの吸着, およびTTCA.Snメルカプチ ドの形成，ならびに活性化試剤（硝酸銀）の板表面への 浸透と, 銀イオンの䢬元析出を促進するものと考えられ る。
このような中程度の親水性溶媒（たとえばシクロへキ サノン）のPVCに対する吸着と膨潤効果は，すでに著 者らによって，水に分散した PVC 粒子と無機イオウ化 合物との反応においても，反応試剤の PVC 粒子内部一 の浸透促進に応用され成果をおさめている?。

な抢, シクロへキサノン水溶液による表面処理効果を Table 4 に示寸が，はく敎強度の增強に効果的なことが わかる。

また,これらのはく離強度は, 1 週閒の常温での保存, $-50^{\circ} \mathrm{C}, 30$ 分, 室温 10 分, $70^{\circ} \mathrm{C}, 30$ 分の熱サイクル試 験1ににおいてを低下しない。

\subsection{PVC メッキに対する TTCA メルカプチトの特} 異性

以上述べたように，PVGのメッキ性を向上させるた めに TTCA・Na を用いる理由の一つは，感応化試郕と の反応により, 還元力を有する TTCA・Sn (II) メルカプ チドを形成させることにある。したがって，このよう な Sn (II) 塩を形成しやすい化合物として, Table 5 に示すような若干のチオール，有機酸または，これらの ナトリウム塩を混練した PVC板の $r_{c}$ ，およびメッキ層 のはく離強度を検討したが，同表から明らかなように， TTCA・Na 以上の勃果を示すものは見いだすことはでき なかった。この理由は不明であるが，それぞれのメルカ プチド，千オールなどの親水性，混練板の $\gamma_{c} ，$ PVC と の混練性, およびメルカプチドの形成のしやすさなどの 要因が複雑に影響し合っているためと考える。さらに T TCA メルカプチドの性質 (Table 2) から予想されるよ うに，TTCA・Sn(II) を混練した PVC 板は，スズメル カプチドの有する還元力のため, 感応化工程を省略し て，直接硝酸銀溶液による活性化入:程を行ない化学メッ キに供することができる。また，銅イオンを還元析出す る能力を有する TTCA の銀または銅メルカプチドを混 鄱した PVC 板は，感応化拉よび活性化工程を省略して 直接化学銅メッキを施行できる特徽を有する。これらの 結果を Table 6 に示すが，最も効果のあるメルカプチド は TTCA の銀塩であり，これを混練した PVC 板は，

Table 5. Effect of thiols on peel adhesion.

\begin{tabular}{|c|c|c|c|}
\hline Thiolsa ${ }^{2}$ & $(\mathrm{phr})$ & $\mid \begin{array}{c}\gamma_{0} \\
(\mathrm{dyn} / \mathrm{cm})\end{array}$ & $\begin{array}{c}\text { Peel adhesion } \\
(\mathrm{kg} / \mathrm{cm})\end{array}$ \\
\hline TTCA $\cdot \mathrm{Na} 3 \mathrm{H}_{2} \mathrm{O}$ & 10 & 32.1 & 1.1 \\
\hline TTCA.2Na $6 \mathrm{H}_{2} \mathrm{O}$ & 13.1 & 33.9 & 0.7 \\
\hline TTCA.3Na $9 \mathrm{H}_{2} \mathrm{O}$ & 16.1 & 34.2 & 0.6 \\
\hline DBTT & 18.1 & 28.7 & 0.2 \\
\hline Thiophenol & 13.5 & 26.1 & $0 \sim 0.1$ \\
\hline$\beta$-Thionaphthol $\cdot \mathrm{Na}$ & 22.4 & 23.3 & $0 \sim 0.1$ \\
\hline$o$-Toluic acid $\cdot \mathrm{Na}$ & 19.3 & 31.8 & 0.2 \\
\hline
\end{tabular}

a) TTCA and DBTT refer to Table 1 
中村・梌・本

Table 6. Effect of TTCA-mercaptide on peel adhesion.

\begin{tabular}{|c|c|c|c|c|c|c|}
\hline \multicolumn{2}{|c|}{$\begin{array}{l}\left.\text { Mercaptide }{ }^{\mathrm{a}}\right) \\
\text { (phr) }\end{array}$} & \multicolumn{2}{|c|}{$\begin{array}{l}\text { Additive }{ }^{\mathrm{a})} \\
\text { (phr) }\end{array}$} & \multirow{2}{*}{$\frac{\text { Washing process }^{b} \text { ) }}{I}$} & \multirow{2}{*}{$\frac{\left.\text { Plating process }^{\mathrm{c}}\right)}{\text { B }}$} & \multirow{2}{*}{$\begin{array}{c}\begin{array}{c}\text { Peel adhesion } \\
(\mathrm{kg} / \mathrm{cm})\end{array} \\
0.1 \sim 0.2\end{array}$} \\
\hline TTCA.Ag & (10) & $\mathrm{PhG}$ & $(10)$ & & & \\
\hline TTCA.3Ag & $(10)$ & $\mathrm{PhG}$ & $(10)$ & I & B & $0.1 \sim 0.2$ \\
\hline TTCA.Sn (II) & $(10)$ & $\mathrm{PhG}$ & (10) & I & A & 0.2 \\
\hline TTCA.1.5Cu & $(10)$ & $\mathrm{PhG}$ & (10) & I & B & 0 \\
\hline TTCA.3Ag & (10) & $\mathrm{PhG}$ & $(10)$ & II & B & $0.9 \sim 1.0$ \\
\hline TTCA.Sn (II) & $(10)$ & BTG & (10) & II & A & $0.1 \sim 0.2$ \\
\hline
\end{tabular}

a) TTCA, PhG, and BTG refer to Table 1,3, b) I: Washing in water at $30^{\circ} \mathrm{C}$ for $6 \mathrm{hr}$, II : Washing in dimethylformamide at $20^{\circ} \mathrm{C}$ for $30 \mathrm{sec}$, c) A: After washing process, activation and plating are carried out, B: After washing process, plating is carried out

水洗後直接化学銅メッキを経るだけで，直接電気銅メッす。 キを施行することができる。しかし，水洗操作だけでは 必ずしも十分なはく離強度を得ることはできないので， DMF のような溶媒で混練 PVG 板表面を 30 秒程度腐食 し，水洗後㨁ちに化学銅メッキ，電気銅メッキを施行す れば，はく離強度が増大 $(1 \mathrm{~kg} / \mathrm{cm})$ 寸る (Table 6)。

このようにメッキの前処理工程を大幅に省略できる添 加剤を見いだしたことは，PVC だけでなく，他のプラ スチックのメッキにも適用される期待がもてる。

付記 PVC，グリコール類, 可塑剤, TTCA およびそ の誘導体を提供されました日本ぜオン姝, 日本乳化剂(姝), 大八化学工業(侏)，三協化成侏)の各社に感謝の意を表しま

\section{文献}

1) Y. Nakamura: J. Appl. Polym. Sci., 16, 2727 (1972)

2) Brit. Pat.: 1008002 (1965)

3) U.S. Pat.: 3629922

4) U.S. Pat.: 3620834

5) 日特公告：昭 45-26238

6）中村儀郎ら：公害, 7, 257 (1972); 中村儀郎ら : 化学工業, 16, No. 1, 81 (1972)

7) 浜村保次：宸化, 31, 703 (1957)

8) L. Anderson: J. Polym. Sci., A10, 1963 (1972)

9）中村儀郎，森 邦夫：第 22 回年次大会要旨集 (II), 464 (1973) 